\title{
SIG Lokasi Fasilitas dan Pelayanan Kesehatan Berbasis Android di Provinsi Gorontalo
}

Satriadi D. Ali., S.Kom., M.Kom ${ }^{1}$, Citra Yustitya Gobel, S.SI., M.Kom ${ }^{2}$

${ }^{1,2}$ Sistem Informasi, STMIK Ichsan, Gorontalo, Indonesia

${ }^{1}$ ady.stmik@gmail.com, ${ }^{2}$ gobelcitra87@gmail.com

\section{Article Info}

Article history:

Received, 30/10/2021

Revised, 13/11/2021

Accepted, 26/11/2021

\section{Kata Kunci:}

Fasilitas Kesehatan

Android

Sistem Informasi Geografis

\begin{abstract}
ABSTRAK
Permasalahan dalam penelitian ini berdasarkan data yang dikumpulkan[1] persentase penduduk yang memiliki keluhan kesehatan dan berobat jalan dari tahun ke tahun meningkat dimana tahun 2017 sekitar 44\%, tahun 2018 menjadi $46 \%$ dan 2019 meningkat 51\% hingga tahun 2020 terjadi peningkatan drastis yang disebabkan oleh penyebaran wabah covid 19, salah satu penyebab terjadinya peningkatan karena masyarakat sangat bergantung pada pelayanan Rumah sakit umum dan kurangnya informasi masyarakat terkait dengan lokasi, proses pelayanan kesehatan dan sarana prasarana fasilitas kesehatan tingkat pertama. Tujuan dari penelitian ini untuk memudahkan masyarakat dalam pencarian lokasi dan informasi fasilitas kesehatan yang tersebar di seluruh wilayah provinsi melalui media smartphone android guna mendapatkan pelayanan kesehatan lebih cepat dan tepat, mengingat kebutuhan informasi yang mendesak dan darurat dapat terjadi kapan saja dan dimana saja. Hasil Pengujian sistem pada penelitian ini di peroleh dari beberapa modul yang diuji diantaranya modul input data fasilitas kesehatan memiliki nilai sesuai dimana perhitungan cyclometic comlexity $=3$ dan nilai $\mathrm{VG}=3$, serta hasil pengujian blacbox sistem yang di ujicoba pada aplikasi android sebagai sisi client menghasilkan fungsi-fungsi yang sesuai kebutuhan user.
\end{abstract}

\section{ABSTRACT}

Gorontalo Province has 12 general and special hospitals, 93 health centers, 37 clinics, 352 Polindes and more than 1,200 integrated service posts, all of which are spread across cities and regencies in Gorontalo Province [1]. However, based on the data collected, the percentage of the population who have health complaints and receive outpatient treatment from year to year has increased, where in 2017 it was around 44\%, in 2018 it became 46\% and in 2019 it increased by $51 \%$ until 2020 there was a drastic increase caused by the spread of the covid 19 outbreak, One of the causes of the increase is because the community is very dependent on public hospital services and the lack of public information related to the location, process of health services and other health facilities serve first-level health complaints. The purpose of this study is to make it easier for the public to search for locations and information on health facilities spread throughout the province through android smartphone media in order to get health services more quickly and precisely. The results of the system testing in this study were obtained from several modules tested including the health facility data input module based on the calculation of cyclometic complexity $=3$ and the value of $V G=3$, as well as the results of the blackbox test system that was tested on the android application as the client side to produce functions that fit the needs user.

\section{Penulis Korespondensi:}

Adi,

Program Studi Sistem Informasi,

STMIK Ichsan Gorontalo,

Email: ady.stmik@gmail.com

\section{PENDAHULUAN}


Berdasarkan data yang dikumpulkan[1] persentase penduduk yang memiliki keluhan kesehatan dan berobat jalan dari tahun ke tahun meningkat dimana tahun 2017 sekitar 44\%, tahun 2018 menjadi 46\% dan 2019 meningkat 51\% hingga tahun 2020 terjadi peningkatan drastis yang disebabkan oleh penyebaran wabah covid 19 , salah satu penyebab terjadinya peningkatan karena masyarakat sangat bergantung pada pelayanan Rumah sakit umum dan kurangnya informasi masyarakat terkait dengan lokasi, proses pelayanan kesehatan dan sarana prasarana fasilitas kesehatan lainnya seperti pada puskesmas, klinik, polindes, dan pos pelayanan terpadu yang melayani keluhan kesehatan tingkat pertama. Permasalahan informasi dan komunikasi saat ini dapat di pecahkan menggunakan perkembangan teknologi informasi berbasis smartphone, sehingga tujuan dari penelitian ini untuk memudahkan masyarakat dalam pencarian lokasi dan informasi fasilitas kesehatan yang tersebar di seluruh wilayah provinsi melalui media smartphone android guna mendapatkan pelayanan kesehatan lebih cepat dan tepat, mengingat kebutuhan informasi yang mendesak dan darurat dapat terjadi kapan saja dan dimana saja.

Perancangan Aplikasi menggunakan bahasa pemograman php dan Android sebagai pengelola data spasial dan non spasial yang akan di kolaborasikan dengan perancangan database menggunakan MySQL. Aplikasi akan di implementasikan pada Smartphone berbasis Android dengan memanfaatkan Sistem Informasi Geografis sebagai media untuk mengetahui dan mendapatkan informasi mengenai lokasi fasilitas kesehatan detail serta memberikan panduan kepada pengguna bagaimana lokasi tersebut di capai[2].

Penelitian mengenai sistem informasi geografis pernah dilakukan sebelumya oleh [3], dengan judul" Mapping a hospital using Open Street Map and Graph hopper " dan penelitian oleh[4] judul Sistem Informasi Pelayanan Kesehatan Berbasis Web di Puskesmas" serta Penelitian oleh [5] dengan judul penelitian "Analisa Algoritma Haversine Formula untuk pencarian Lokasi Terdekat Rumah Sakit dan Puskesmas Provinsi Gorontalo". Data layanan informasi yang berkaitan dengan data sarana puskesmas dan rumah sakit belum terinci, sehingga pemerintah kesulitan dalam pengambilan keputusan dalam bentuk peta digital sehingga kebanyakan masyarakat Gorontalo apabila mengalami masalah kesehatan seperti sakit, kecelakaan, meninggal dan lain-lain, akan sering mengalami kesulitan dalam mencari lokasi terdekat layanan kesehatan.

Pada Penelitian sebelumya hanya di fokuskan pada analisa kinerja algoritma haversine dan dibatasi Pencarian lokasi hanya pada Rumah sakit dan puskesmas saja, serta tekologi informasi yang di terapkan masih berbasis website sedangkan dalam penelitian ini pencarian lokasi fasilitas kesehatan yang tersedia di seluruh provinsi gorontalo baik itu Rumah sakit, puskesmas, klinik, Rumah Sakit Bersalin, Polindes dan Posyandu. Penelitian ini dikembangkan dengan perancangan aplikasi Sistem informasi Geografis berbasis smartphone android.

\subsection{Sistem Informasi Geografis}

Sistem Informasi Geografis Merupakan sistem informasi yang berdasar pada data keruangan dan merepresentasikan objek bumi. Dalam GIS sendiri teknologi informasi merupakan perangkat yang membantu dalam menyimpan data, proses data, analisa data, kelola data dan menyajikan informasi[6].

\subsection{Android}

Android menyediakan sejumlah objek untuk menangani peta dalam sistem GIS seperti Map View yang menampilkan peta. Untuk menangani ini, kelas MapActivity ada di sana. Untuk membubuhi keterangan peta itu menyediakan kelas overlay. Bahkan ia menyediakan kanvas yang dengannya seseorang dapat dengan mudah membuat dan menampilkan banyak lapisan di atas peta[7].

\subsection{Pelayanan Kesehatan}

Pelayanan Kesehatan merupakan hal yang sangat penting bagi kehidupan manusia. Kesehatan harus dijaga demi kelangsungan hidup manusia. Jenis variasi penyakit yang menyerang sistem kekebalan tubuh manusia, melakukan pencegahan dan pengobatan penyakit menjadi sangat diperlukan. Ini adalah alasan utama seseorang mencari fasilitas dan pelayanan kesehatan dengan cepat dan tepat dalam menghadapi penyakitnya atau biasa disebut check up[8]. 


\section{METODE PENELITIAN}

Penelitian ini menggunakan metode Research and Development atau yang dikenal dengan metode Penelitian dan Pengembangan[9]. Metode ini didefinisikan sebagai metode penelitian yang digunakan untuk menghasilkan produk tertentu dan menguji keefektifan produk tersebut. Tahapan Penelitian yang dilakukan sebagai berikut :

\subsection{Study Literatur}

Sebagai Pedoman Pengembangan sistem telah dilakukan studi literatur berupa buku tentang Sistem Informasi Geografis[10], dan Sistem informasi berbasis android [11]serta tools- tools pedukung yang digunakan[12]. Mengkaji jurnal ilmiah terkait sistem Informasi geografis berbasis website[13] dan sistem informasi geografis fasilitas kesehatan berbasis android[14].

\subsection{Identifikasi Masalah}

Identifikasi Masalah dalam penelitian ini adalah Terjadi peningkatan masalah kesehatan disebabkan kurangnya informasi masyarakat terkait lokasi kesehatan, proses pelayanan kesehatan dan sarana prasarana fasilitas kesehatan terdekat baik di daerah domisili maaupun saat berkunjung ke daerah lain di wilayah provinsi gorontalo.

\subsection{Merumuskan Tujuan}

Tujuan Penelitian ini adalah Mengembangkan Sistem Informasi pencarian Lokasi Fasisiltas Kesehatan berbasis Smartphone android untuk memudahkan masyarakat dalam pencarian lokasi dan informasi fasilitas kesehatan yang tersebar di seluruh wilayah provinsi gorontalo guna mendapatkan pelayanan kesehatan yang cepat dan tepat.

\subsection{Pengumpulan Data}
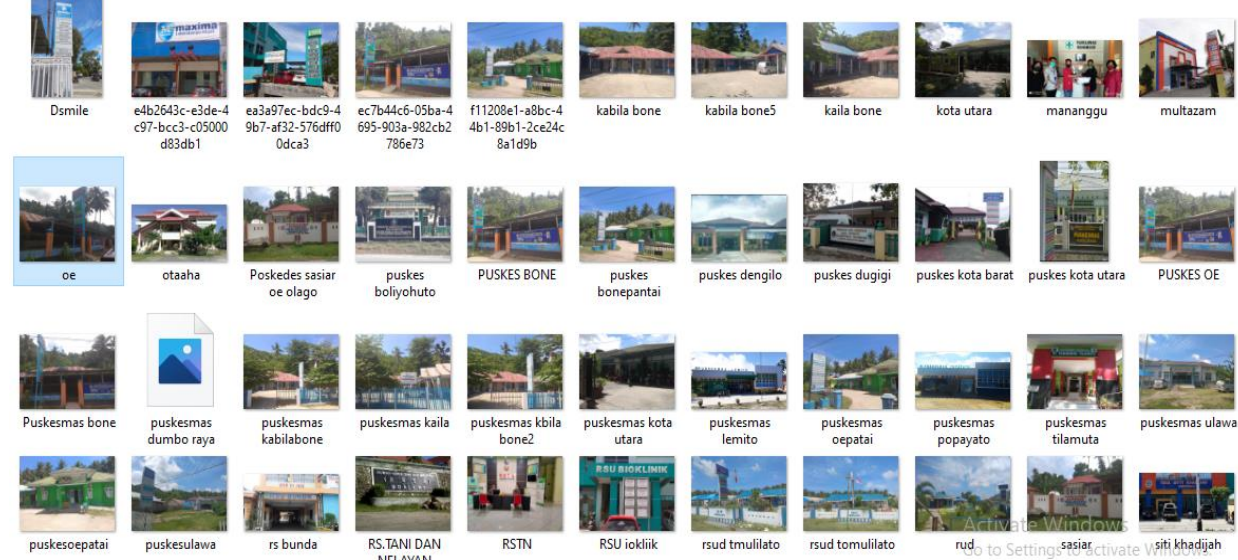

Gambar 1. Data Hasil Observasi

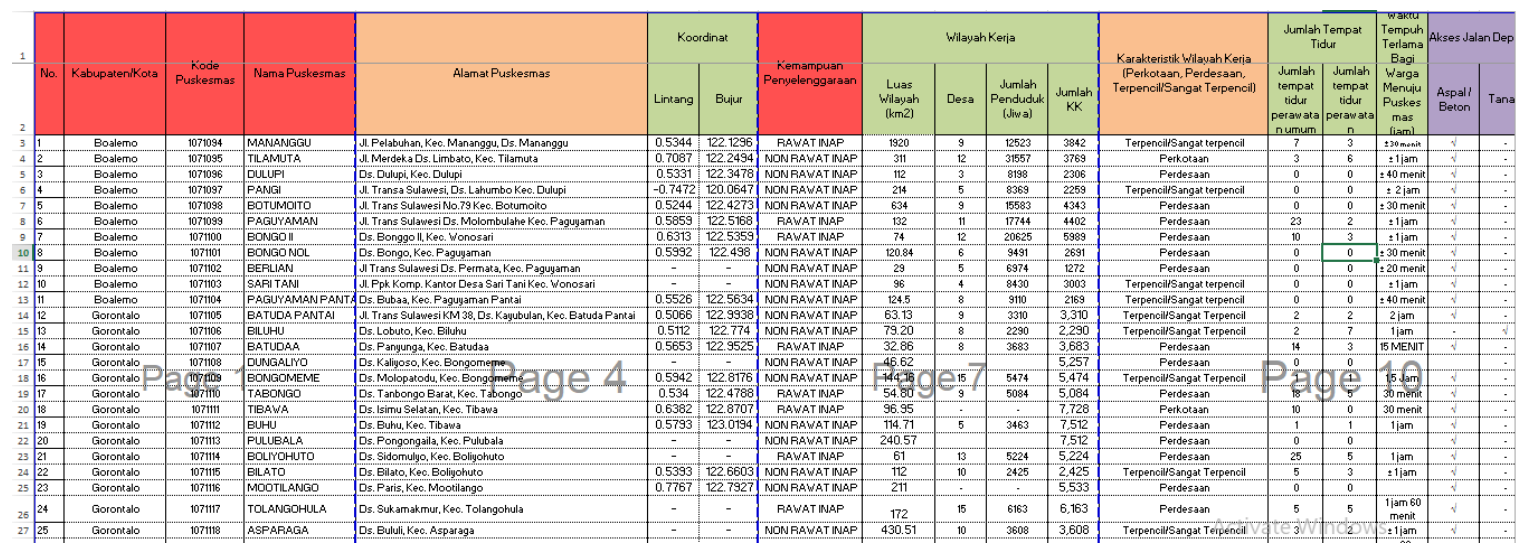

Gambar 2. Data Hasil Interview

\subsection{Perancangan System}

Perancangan system sebagai tahap setelah melakukan analisis dari siklus pengembangan sistem, penjabaran dari bantuanbantuan fungsional, persiapan untuk perancangan system pendukung keputusan sebagai implementasi dapat berupa penggambaran, perencanaan dan 
berupa elemen yang bias di jadikan penyambung atau penyatu antara komponen perangkat keras dengan perangkat lunak [15].

\section{a. Desain Use Case Diagram}

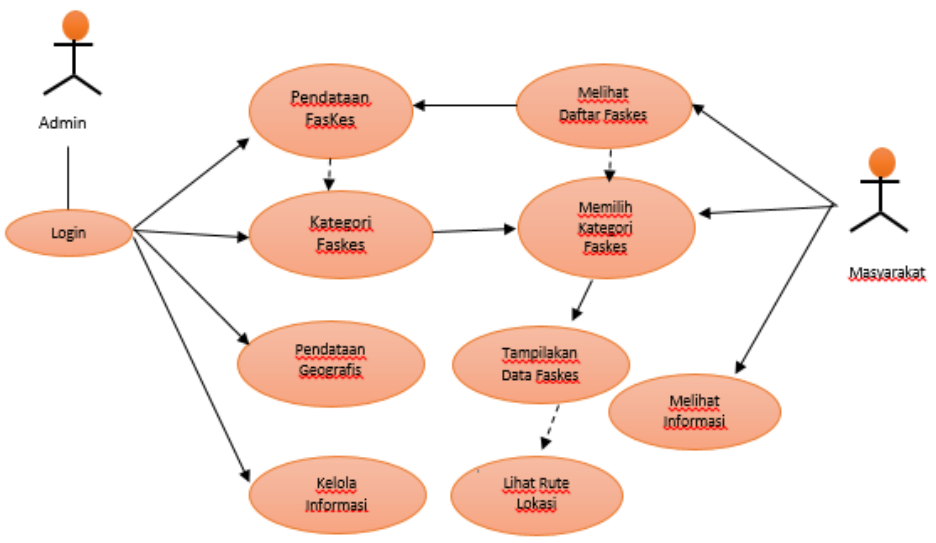

Gambar 3. Use Case Diagram

Pada Use case diagram tersebut digambarkan bahwa pada sistem terdapat 2 aktor yaitu server sebagai administrator pengelola data lokasi fasilitas kesehatan dan masyarakat sebagai user. Aktor admin wajib melakukan login saat masuk dalam proses pegelolaan data, data yang dikelola adalah input data lokasi fasilitas kesehatan, kategori setiap fasilitas kesehatan seperti kategori rumah sakit, Puskesmas dan klinik, kelola data geografis untuk pemetaan lokasi faskes hingga input data informasi sarana dan prasarana setiap fasilitas kesehatan yang di input.

Aktor pengguna (masyarakat) dapat mengakses view maps lokasi fasilitas kesehatan, melihat tampilan data informasi lengkap faskes dan route menuju lokasi faskes yang di butuhkan. User juga dapat melihat seluruh daftar faskes yang ada di provinsi gorontalo terutama fasilitas kesehatan terdekat dengan tempat user berada.

b. Desain Activity Diagram Modul Lokasi Fasilitas Kesehatan

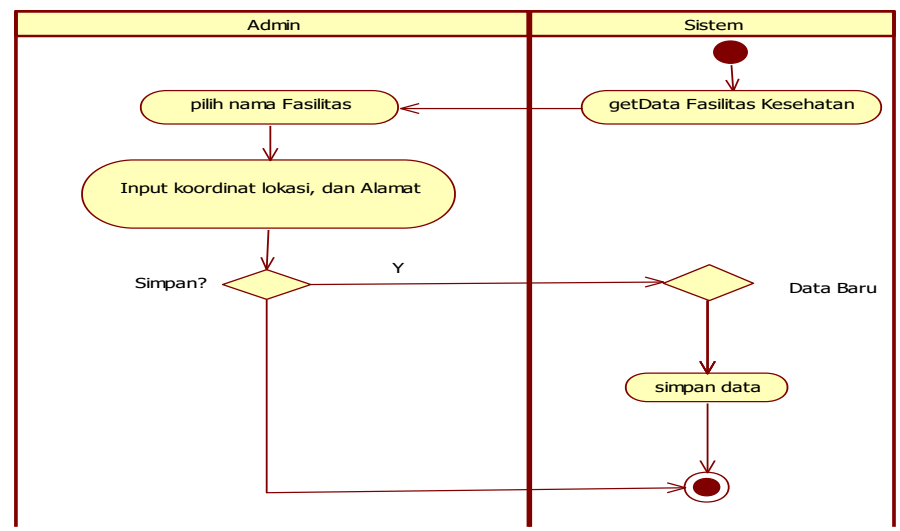

Gambar 4. Activity Diagram Modul Lokasi Fasilitas Kesehatan

c. Sequence Diagram View Data Fasilitas Kesehatan 


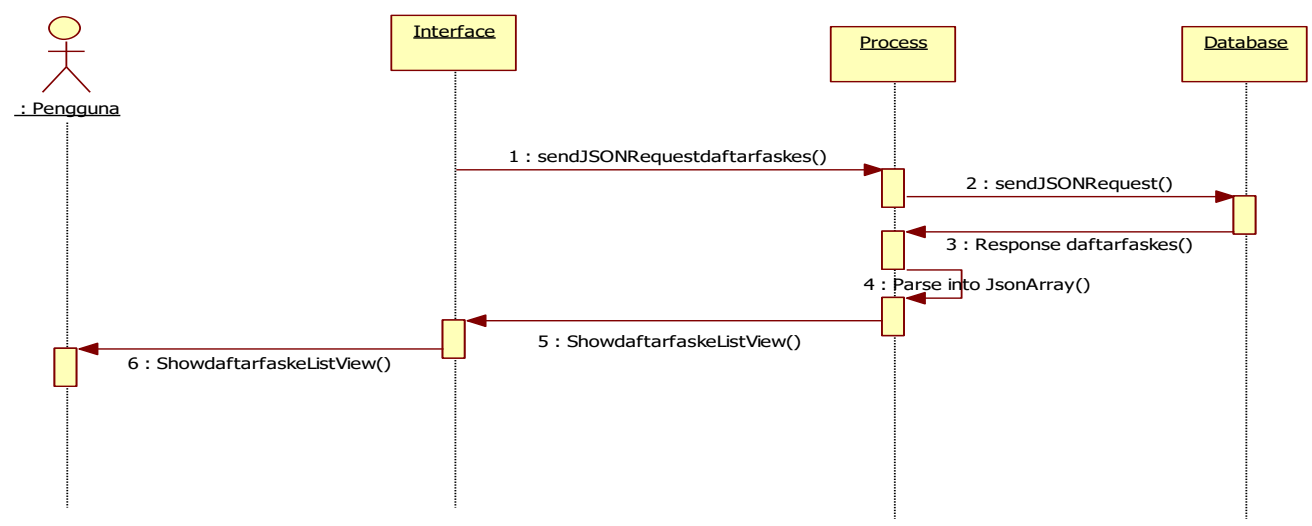

Gambar 5. Sequence Diagram View Data Fasilitas Kesehatan

\section{HASIL DAN ANALISIS}

\subsection{Desain User Interface pada sisi Server (website)}

Berdasarkan use case diagram sistem bahwa sistem terbagi sisi server dan sisi cliet dimaa server mejadi akses untuk mengelola data dengan desain tampilan pada website terdapat beberapa fitur diantaranya sebagai berikut :

1). Tampilan Login

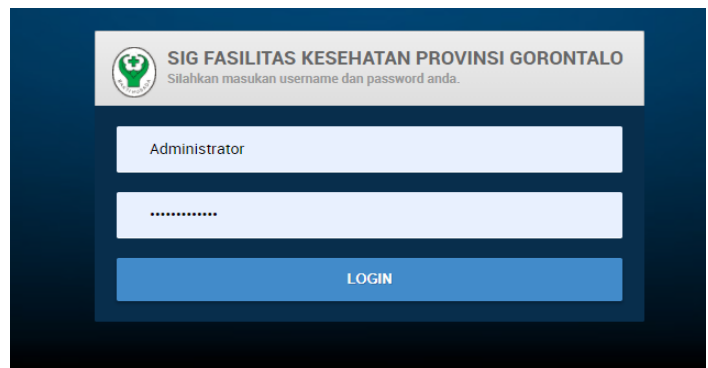

Gambar 3. Tampilan Login Admin

Tampilan login akan muncul saat pertama kali halaman website diakses, pada jendela login terdapat pengisian username dan password admin web.

2). Tampilan List Fasilitas kesehatan

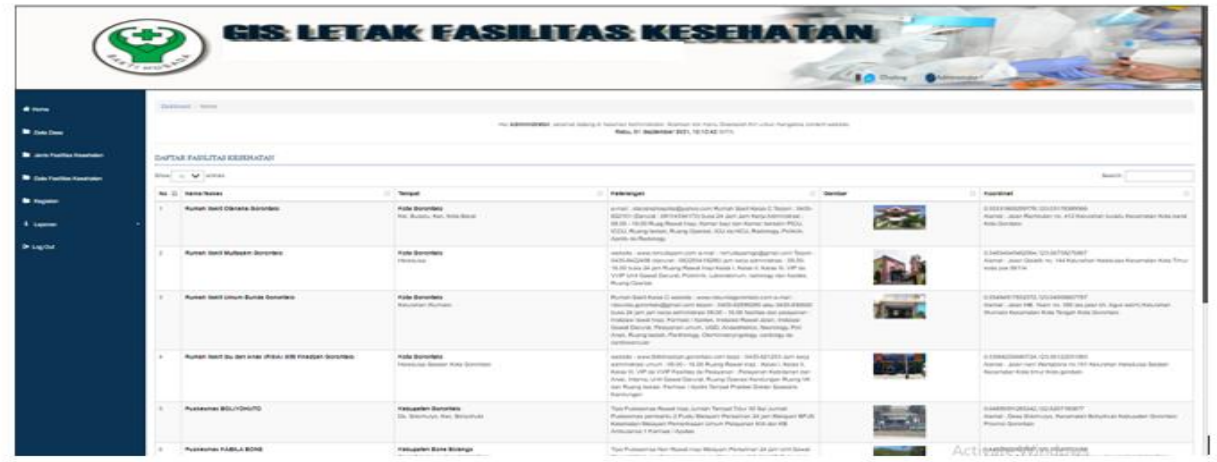

Gambar 4. Tampilan List Fasilitas Kesehatan

Form Tampilan List Fasilitas Kesehatan menampilkan daftar data faskes dengan informasi nama faskes, Alamat lengkap,sarana dan prasarana, foto faskes serta titik koordiat lokasi maps. 


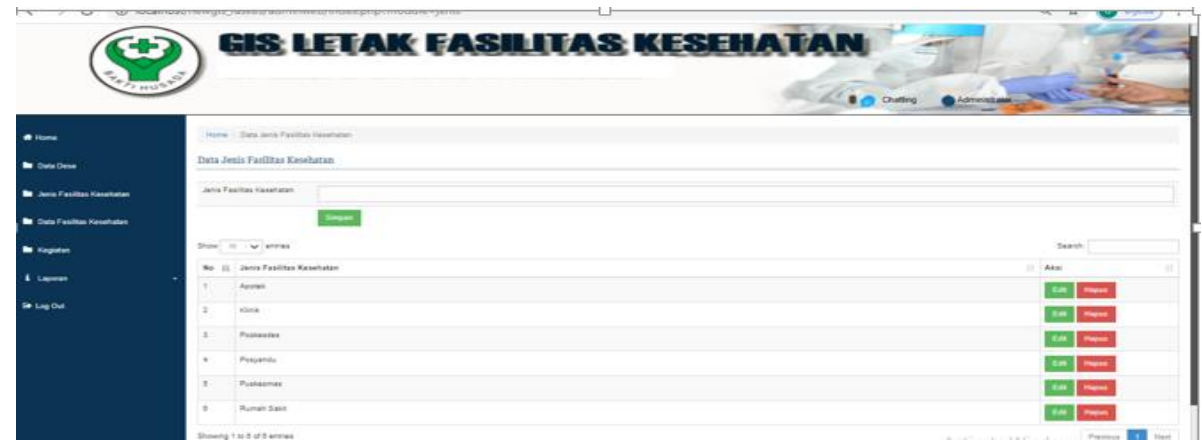

Gambar 5. Tampilan Kategori Faskes

Form Tampilan kategori Fasilitas Kesehatan menampilkan daftar kategori atau jenis faskes yang ada di provinsi gorontalo yaitu Kategori Rumah Sakit, Puskesmas, Klinik, puskes pembantu (Pustu), posyandu, dan laboratorium.

\subsection{Desain User Interface pada sisi Client (Android)}

Pada sisi client, sistem dapat di akses menggunakan smartphone android da terdapat eerapa fitur yag di racag khusus untuk masyarakat diantaraya sebagai berikut :

1). Tampilan Splash Screen dan Home

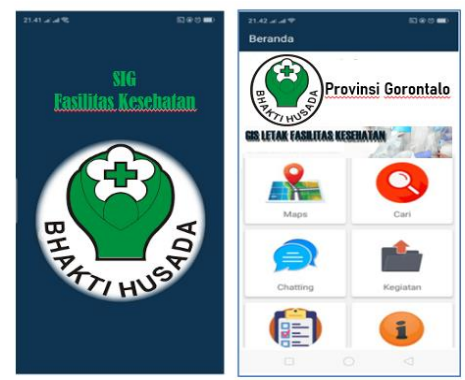

Gambar 6. Splash Screen dan Home

Splash Screen merupakan tampilan awal saat user membuka aplikasi android, selanjutya user akan di arahkan ke halaman beranda (home), sedangkan pada tampilan home akan tampil fitur-fitur yang dapat di akses user seperti fitur maps akan menampilkan petunjuk arah megguakan peta digital saat user melakukan perjalanan ke lokasi faskes, pada fitur pecarian akan menampilkan semua data detail dari fasilitas keseahatan di provinsi gorontalo, fitur chat dapat digunakan user untuk melakukan komunikasi dengan pihak pelayanan kesehatan jika mendapatkan kendala, dan fitur kegiatan akan menampilkan informasi kegiatan yang dilakukan oleh dinas kesehatan seperti pelayanan vaksinasi, pelayanan kesehatan gratis dan informasi lainya.

2). Tampila Maps

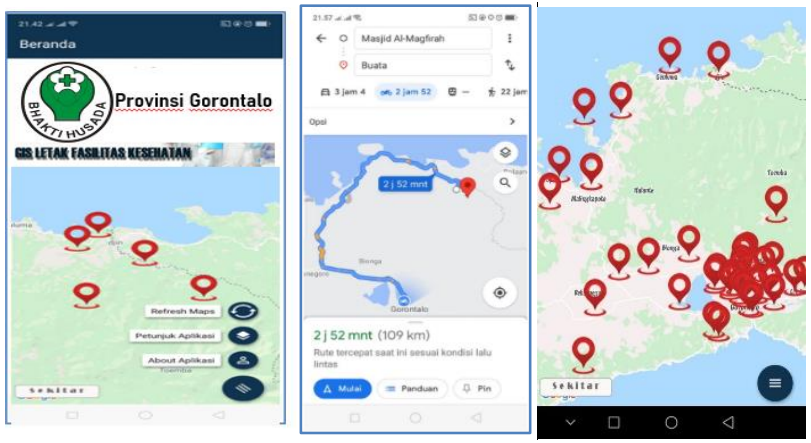

Gambar 7. Maps dan route

Fitur Maps Pada aplikasi merupakan petunjuk arah menggunakan peta digital dari fasilitas google, fitur ini adalah fitur pertama yang dapat di manfaatkan user saat melakukan pecarian fasilitas kesehatan sekaligus terdapat petunjuk route perjalanan.

\subsection{Pengujian Perangkat Lunak}


Pengujian sistem dilakukan untuk mengukur apakah sistem yang dikembangkan telah sesuai dan dapat berjalan dengan alur yang telah direncanakan sebelumnya. Dalam pengujian sistem penulis menggunakan dua metode, yaitu white box dan black box

1) white box
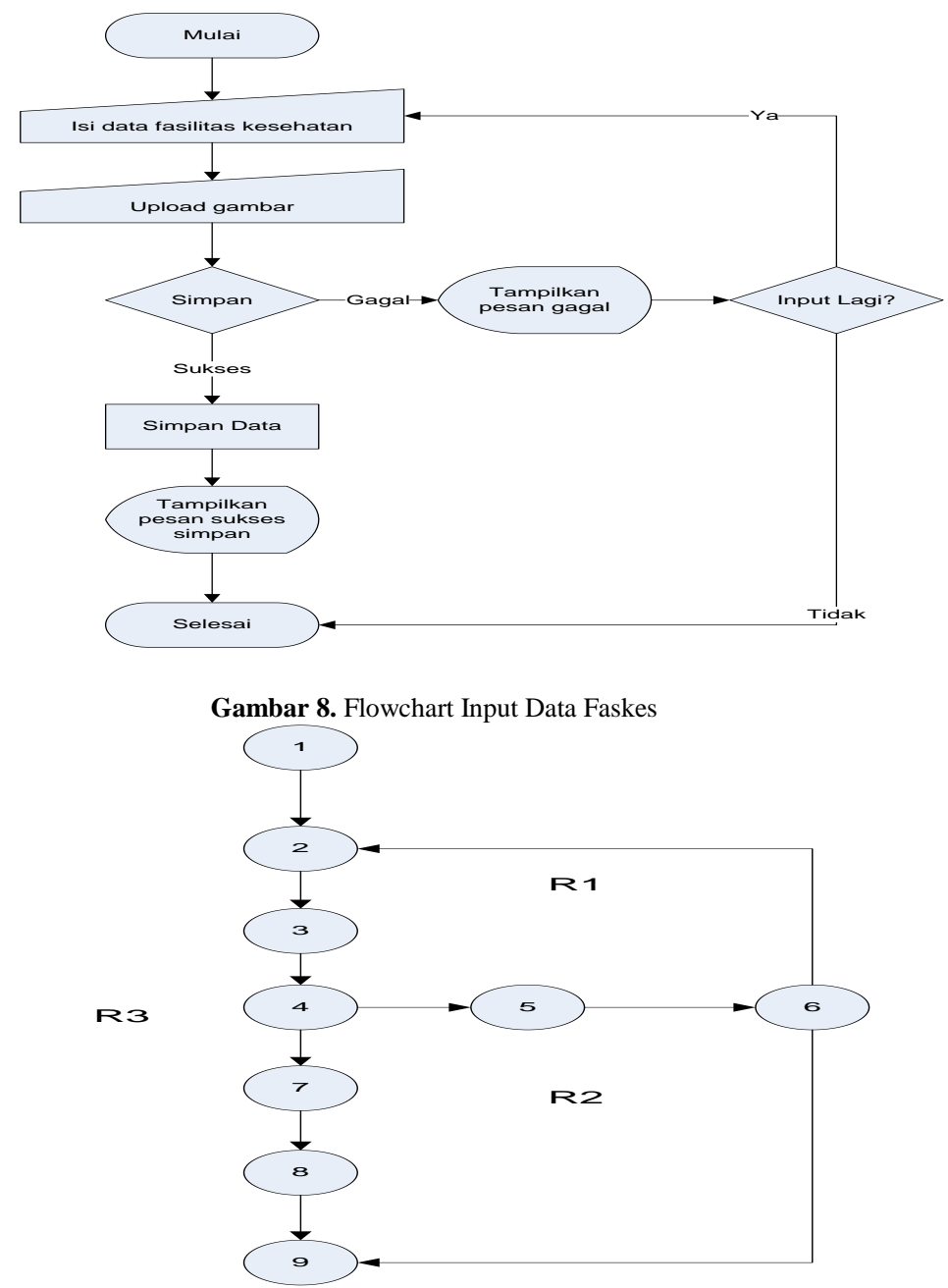

Gambar 9. Flowgraph Input Data Faskes

Dari flowgraph untuk modul input data fasilitas kesehatan di atas di ketahui bahwa nilai:

- $\operatorname{Region}(\mathrm{R})=3 \rightarrow \mathrm{R} 1, \mathrm{R} 2, \mathrm{R} 3$

- Predicate Node $(\mathrm{P})=2$

- $\quad$ Node $=9$

- $\quad$ Edge $=10$

1. $\mathrm{V}(\mathrm{G})=\mathrm{E}-\mathrm{N}+2$

$$
=(10-9)+2=3
$$

2. $\mathrm{V}(\mathrm{G})=($ Predicate Node $(\mathrm{P})+1)=2+1=3$

3. Ciclometic Complexity $(\mathrm{CC})=\mathrm{R} 1, \mathrm{R} 2, \mathrm{R} 3=\mathbf{3}$

Independent Path untuk modul input data fasilitas kesehatan yaitu:

$\mathrm{R} 1=1,2,3,4,5,6,2 \ldots$

$\mathrm{R} 2=1,2,3,4,5,6,9$

$\mathrm{R} 3=1,2,3,4,7,8,9$

Berdasarkan hasil pengujian di atas diperoleh :

- $\quad \mathrm{V}(\mathrm{G})=3$

- Cyclometic Complexity $(\mathrm{CC})=\mathbf{3}$ 
Maka dapat disimpulkan bahwa alur logika untuk modul input data fasilitas kesehatan adalah efektif dan efisien.

\section{2) black box}

\section{Tabel 1. Pengujian blacbox}

\begin{tabular}{|c|c|c|c|c|}
\hline No & Input/Event & Proses & Output/Next State & Hasil Pengujian \\
\hline 1. & Jika menu Maps ditekan & $\begin{array}{l}\text { data.add (new } \\
\text { AdapterGidViewItem (getResources ().getString (R.string.men } \\
\text { u_peta), ContextCompat.getDrawable(getActivity (), } \\
\text { R.drawable.c2))); } \\
\text { startActivity (new Intent (getActivity (), } \\
\text { MapsActivity.class)); }\end{array}$ & $\begin{array}{l}\text { Tampilkan activity maps fasilitas } \\
\text { kesehatan }\end{array}$ & Sesuai \\
\hline 2. & Jika menu cari ditekan & $\begin{array}{l}\text { data.add (new } \\
\text { AdapterGidViewItem (getResources (). getString (R. string.men } \\
\text { u_cari), ContextCompat.getDrawable(getActivity(), } \\
\text { R.drawable.c1))); } \\
\text { startActivity(new Intent (getActivity(), } \\
\text { LihatFaskes.class)); }\end{array}$ & Tampilkan activity faskes & Sesuai \\
\hline 3. & $\begin{array}{l}\text { Jika menu data Order Lapangan } \\
\text { ditekan }\end{array}$ & $\begin{array}{l}\text { data.add (new } \\
\text { AdapterGidViewItem (getResources () . getString (R. string.men } \\
\text { u_komentar), ContextCompat.getDrawable(getActivity (), } \\
\text { R.drawable.chat))); } \\
\text { startActivity (new Intent (getActivity(), } \\
\text { LihatChat.class)); }\end{array}$ & Tampilkan activity Lihat Chat & Sesuai \\
\hline 4 & Jika menu kegiatan di tekan & $\begin{array}{l}\text { data.add (new } \\
\text { AdapterGridViewItem (getResources ().getString (R.string.men } \\
\text { ukkegiatan), ContextCompat.getDrawable(getActivity(), } \\
\text { R.drawable.c8))); }\end{array}$ & Tampilkan activity kegiatan & Sesuai \\
\hline 5 & $\begin{array}{l}\text { Jika menu petunjuk aplikasi di } \\
\text { tekan }\end{array}$ & $\begin{array}{l}\text { data.add (new } \\
\text { AdapterGridViewItem (getResources ().getString (R.string.men } \\
\text { u_petunjuk), ContextCompat.getDrawable(getActivity(), } \\
\text { R.drawable.c9))); } \\
\text { startActivity (new Intent (getActivity(), } \\
\text { ActivityPetunjuk.class)); }\end{array}$ & Tampilkan activity petunjuk & Sesuai \\
\hline
\end{tabular}

\section{KESIMPULAN}

Dari hasil penelitian di atas maka dapat disimpulka bahwa Aplikasi dirancang sederhana sehingga dapat memudahkan masyarakat untuk dapat mencari lokasi fasilitas kesehatan di provinsi Gorontalo. Dalam aplikasi ini terdapat fitur chat dan informasi kegiatan terkait pelayanan kesehatan sehingga masyarakat mendapatkan informasi kesehatan up to date dan dapat berkomunikasi dengan pihak pelayan kesehatan.Berdasarkan pengujian sistem whitebox dengan hasil yang seimbang yaitu Cyclomatic Complexity $(\mathrm{CC})=3$, dan pengujian blackbox dengan beberapa sampel pengujian dengan hasil sesuai, maka disimpulkan bahwa sistem yang dirancang lebih efektif dan efisien dibandingkan secara manual.

\section{UCAPAN TERIMA KASIH}

Alhamdulillahirabilalaamiin atas ijin Allah SWT. Penulis mengucapkan terima kasih kepada Pihak Kementrian Riset dan Teknologi serta Perguruan Tinggi yang telah memberi dukungan financial terhadap penelitian ini serta semua pihak yang mendukung dalam penyelesaian penelitian.

\section{REFERENSI}

[1] D. Kesehatan, "Data Fasilitas dan Pelayanan Kesehatan Provinsi Gorontalo," Gorontalo, 2021.

[2] N. Noor, K. Sari, and N. Heldayanti, "KESEHATAN BPJS DI KOTA PALANGKA RAYA," vol. 14 , no. 1 , pp. 30-39, 2020.

[3] K. A. F. A. Samah, S. Ibrahim, N. Ghazali, M. Suffian, M. Mansor, and W. A. Latif, "Mapping a hospital using OpenStreetMap and Graphhopper : A navigation system," vol. 9, no. 2, pp. 661-668, 2020.

[4] P. Andrianto and A. Nursikuwagus, "Sistem Informasi Pelayanan Kesehatan Berbasis Web di Puskesmas," J. Pros. Semin. Nas. Komput. dan Inform., vol. 1, pp. 978-602, 11AD.

[5] Farid and Y. Yunus, "Analisa Algoritma Haversine Formula Untuk Pencarian," Ilk. J. Ilm., vol. 9, pp. 353-355, 2017.

[6] D. I. M. Den, "RUMAH SAKIT ATAU PUSKESMAS," 2013.

[7] Y. Herdiana, "Location Based Services using Android Mobile Operating System Operating System," no. Aalt M.

[8] A. Rahmi, I. N. Piarsa, and P. W. Buana, "FinDoctor - Interactive Android Clinic Geographical Information System Using Firebase and Google Maps API,” no. 7, pp. 8-12, 2017. 
JSAI : Journal Scientific and Applied Informatics

Vol. 4, No. 3, November 2021, hal. 346 354

E-ISSN: 2614-3054; P-ISSN: 2614-3062, Terakreditasi Kemenristekdikti, Sinta 5

[9] P. D. Sugioo, Metode Penelitian dan Pengembangan (Research and Development / R\&D), Kesatu. Bandung: Alfabeta, 2019.

[10] Awangga Rolly Maulana, Pengembangan Sistem Informasi Geografis Berbasiskan Open Source, Pertama. Bandug: Alfabeta, 2019.

[11] Safaat Nazruddin H, Pemograman Aplikasi Mobile Smartphone dan tablet PC berbasis Android. Bandung: Informatika, 2015.

[12] Safaat Nazruddin H, Aplikasi berbasis Android. Bandung: Informatika, 2015.

[13] O. V Bondarenko, "The didactic potential of virtual information educational environment as a tool of geography students training," pp. 13-23.

[14] D. I. Kabupaten and B. Berbasis, "SISTEM INFORMASI GEOGRAFIS (SIG) FASILITAS KESEHATAN DI KABUPATEN BUNGO BERBASIS MOBILE,” vol. 4, no. 1, 2016.

[15] A. S. S. M. Rosa, Rekayasa Perangkat Lunak Terstruktur dan berorientasi Objek. Bandung: Informatika, 2019. 